\title{
Duodenal microflora in infants with acute and persistent diarrhoea
}

\author{
I D HILL, M D MANN, L MOORE, AND M D BOWIE \\ Department of Paediatrics and Child Health, Red Cross War Memorial Children's Hospital, Institute \\ of Child Health, University of Cape Town
}

SUMMARY The duodenal bacterial population was determined qualitatively and quantitatively in 3 groups of infants with diarrhoeal disease of varying duration. Infants with acute self limiting diarrhoea (group 1) had an abnormal overgrowth of organisms in the upper small bowel which was similar to that found in infants whose diarrhoea persisted after 4 days in hospital (group 2). The total duodenal organism count in infants with diarrhoea persisting after 7 days in hospital (group 3) was almost 100 times greater than either of the other groups. The findings may have important implications in preventing persistent diarrhoea from becoming protracted.

Bacterial overgrowth of the upper small bowel occurs in infants with protracted diarrhoea. ${ }^{1}$ These organisms may be either directly or indirectly responsible for prolonging the condition ${ }^{2} 3$ and the dramatic reduction of stool output following treatment with a combination of antibiotics and cholestyramine given orally to infants with persistent diarrhoea ${ }^{4}$ supports this.

Most studies have been on infants who have had diarrhoea for 2 or more weeks ${ }^{156}$ and the stage during progression from acute to protracted diarrhoea when appreciable overgrowth of organisms occurs is unknown. In this study the duodenal bacterial population was determined both qualitatively and quantitatively in 3 groups of infants with diarrhoeal disease of varying duration. The results were compared with those reported for healthy infants and infants with diarrhoea and an attempt was made to establish the stage during the diarrhoeal disease when bacterial proliferation occurs since this may have important implications for treatment.

\section{Patients and methods}

Twenty one male infants between the age of 6 weeks and 1 year were studied. All had a history of diarrhoea of less than 48 hours duration before admission to hospital for rehydration with intravenous fluids. They had not received antibiotics for at least 2 weeks before admission and had not had diarrhoea during the preceding month. Infants with features of other systemic disease (eg pneumonia) were excluded as were any whose first stool culture showed Salmonella, Shigella or Campylobacter. Routine investigations and management of the infants has been described. ${ }^{7}$ The day of admission to hospital was designated day 0 and the infants were nursed on balance beds to enable accurate measurements of stool output to be made.

Nine infants were taken into the study on day 0 and investigated on day 1. In 6 of these diarrhoea was acute and self limiting and resolved completely within 72 hours of admission to hospital. These infants constituted group 1. The remaining 3 had continuing diarrhoea and were excluded from the study. A further 12 infants with persistent dehydrating diarrhoea were studied. Six of these were taken into the study on day 3 and investigated on day 4 (group 2) and 6 were taken into the study on day 6 and investigated on day 7 (group 3). Infants in groups 2 and 3 had persistent diarrhoea with a daily stool weight exceeding $30 \mathrm{~g} / \mathrm{kg}$ bodyweight on the day of the investigation.

On the day of study the infant was fasted for 4 hours. A throat swab was taken before a sterile double lumen replogle tube was passed orogastrically. The position of the tube tip in the body of the stomach was confirmed by fluoroscopy and a 3-5 ml sample of gastric contents was aspirated with a sterile syringe. The tube was flushed with sterile water and then advanced under direct vision with fluoroscopy until it lay in the third part of the duodenum. Duodenal fluid was aspirated and the first 3-5 $\mathrm{ml}$ was discarded to reduce possible contamination with gastric contents. A further $1 \mathrm{ml}$ of fluid was then aspirated for bacterial culture.

All specimens were immediately plated out and 
Table 1 Age and weight after rehydration of patients

\begin{tabular}{|c|c|c|c|c|c|c|}
\hline \multicolumn{3}{|c|}{ Group I } & \multicolumn{2}{|l|}{ Group 2} & \multicolumn{2}{|l|}{ Group 3} \\
\hline Case & $\begin{array}{l}\text { Age } \\
\text { (Mths) }\end{array}$ & $\begin{array}{l}\text { Weight } \\
(\boldsymbol{K g})\end{array}$ & $\begin{array}{l}\text { Age } \\
\text { (Mths) }\end{array}$ & $\begin{array}{l}\text { Weight } \\
(\boldsymbol{K g})\end{array}$ & $\begin{array}{l}\text { Age } \\
\text { (Mths) }\end{array}$ & $\begin{array}{l}\text { Weight } \\
(\mathrm{Kg})\end{array}$ \\
\hline $\begin{array}{l}1 \\
2 \\
3 \\
4 \\
5 \\
6\end{array}$ & $\begin{array}{l}2 \cdot 25 \\
5 \cdot 50 \\
6 \cdot 75 \\
5 \cdot 50 \\
4 \cdot 00 \\
2 \cdot 25\end{array}$ & $\begin{array}{l}5 \cdot 91 \\
6 \cdot 03 \\
7 \cdot 50 \\
6 \cdot 52 \\
5 \cdot 94 \\
4 \cdot 50\end{array}$ & $\begin{array}{l}8 \cdot 75 \\
2 \cdot 75 \\
5 \cdot 00 \\
4 \cdot 00 \\
2 \cdot 75 \\
3 \cdot 75\end{array}$ & $\begin{array}{l}6 \cdot 98 \\
5 \cdot 30 \\
6 \cdot 00 \\
4 \cdot 80 \\
5 \cdot 00 \\
3 \cdot 04\end{array}$ & $\begin{array}{l}2 \cdot 75 \\
4 \cdot 75 \\
4 \cdot 50 \\
8 \cdot 50 \\
5 \cdot 25 \\
5 \cdot 25\end{array}$ & $\begin{array}{l}5 \cdot 00 \\
4 \cdot 55 \\
5 \cdot 00 \\
6 \cdot 40 \\
5 \cdot 15 \\
5 \cdot 40\end{array}$ \\
\hline
\end{tabular}

cultured both aerobically and anaerobically. The plates cultured under aerobic conditions were examined after 24 hours while those in the anaerobic Gas Pak jars were examined only after 5 days incubation. Organisms were identified by their colony appearance and growth on selective culture media and the identification confirmed by biochemical reactions and gram staining. ${ }^{8}$ Quantitative estimates of organisms in the duodenal fluid were determined by tenfold serial dilution. The first stool specimen passed after the intubation was also cultured both aerobically and anaerobically and the bacterial flora qualitatively determined.

The bacterial flora of the duodenum was compared to that from a throat swab, gastric aspirate, and stool in each case. The duodenal aspirate from the 3 groups was compared for the variety of organisms isolated, numbers of individual organisms, and total organism count per $\mathrm{ml}$ of duodenal juice. These results were compared with those reported for healthy infants and infants with

Table 2 Bacterial flora isolated from the throat swab, gastric aspirate (asp), and stool of infants in group 1

\begin{tabular}{llll}
\hline & Throat swab & Gastric asp & Stool \\
& No & No & No \\
\hline Lactobacillus & 5 & 5 & 6 \\
Escherichia coli & & 1 & 6 \\
Strep viridans & 6 & 4 & 1 \\
Strep salivarius & 6 & 4 & 2 \\
Strep mitis & 5 & 4 & 1 \\
Staph aureus & 5 & 5 & 3 \\
Staph epidermidis & 3 & 2 & 3 \\
Veillonella & 6 & 4 & 6 \\
Strep faecti!is & 6 & 4 & 5 \\
Yeasts & 2 & 2 & 3 \\
Fusobacterium & 1 & 1 & 1 \\
Klebsiella & 2 & 2 & 1 \\
Haemophilus & 3 & \\
Diphtheroids & 3 & 2 & 2 \\
Neisseria & 1 & 4 & 4 \\
Candida albicans & 5 & 2 & 3 \\
Bacteroides & 2 & 4 & \\
Proteus & 3 & 2 & \\
Propionibacterium & & & \\
Anaerobic streptococci & & & \\
Pneumococi & & & \\
Micrococci & & & \\
\hline
\end{tabular}

Table 3 Bacterial flora isolated from the throat swab, gastric aspirate (asp), and stool of infants in group 2.

\begin{tabular}{llll}
\hline & Throat swab & Gastric asp & $\begin{array}{l}\text { Stool } \\
\text { No }\end{array}$ \\
\hline Lactobacillus & 2 & 4 & 4 \\
Escherichia coli & 1 & 3 & 6 \\
Strep viridans & 5 & 4 & \\
Strep salivarius & 5 & 4 & \\
Strep mitis & 4 & 3 & 4 \\
Staph aureus & 4 & 4 & 3 \\
Staph epidermidis & 3 & 1 & 1 \\
Veillonella & 4 & 3 & 5 \\
Strep faecalis & 4 & 1 & 1 \\
Yeasts & 1 & 1 & 2 \\
Fusobacterium & 3 & 2 & 1 \\
Klebsiella & 3 & & \\
Haemophilus & & 1 & 3 \\
Diphtheroids & 3 & 3 & 5 \\
Neisseria & 5 & 3 & \\
Candida albicans & 2 & 1 & \\
Bacteroides & 1 & & \\
Proteus & 1 & & \\
Propionibacterium & & 1 & \\
Anaerobic streptococci & & & \\
Pneumococci & & & \\
Micrococci & 1 & & \\
\hline
\end{tabular}

diarrhoeal disease. Where applicable the KruskalWallis one way analysis of variance was employed in the comparison between the groups.

\section{Results}

The age and fully rehydrated weight of the patients are shown in Table 1 and no statistical difference between the groups for either of these parameters $(P>0.05)$ was found. The organisms isolated from the throat swab, gastric aspirate, and stool in each group are shown in Tables $2-5$. The variety of

Table 4 Bacterial flora isolated from the throat swab, gastric aspirate (asp), and stool of infants in group 3

\begin{tabular}{|c|c|c|c|}
\hline & $\begin{array}{l}\text { Throat swab } \\
\text { No }\end{array}$ & $\begin{array}{l}\text { Gastric asp } \\
\text { No }\end{array}$ & $\begin{array}{l}\text { Stool } \\
\text { No }\end{array}$ \\
\hline Lactobacillus & 5 & 4 & 4 \\
\hline Escherichia coli & 2 & 5 & 6 \\
\hline Strep viridans & 6 & 5 & \\
\hline Strep salivarius & 5 & 5 & $\because$ \\
\hline Strep mitis & 6 & 4 & 1 \\
\hline Staph aureus & 5 & 3 & 4 \\
\hline Staph epidermiodis & 3 & 3 & 5 \\
\hline Veillonella & 5 & 3 & -4 \\
\hline Strep faecalis & 4 & 5 & 5 \\
\hline Yeasts & & 1 & 1 \\
\hline Fusobacterium & 4 & 3 & 2 \\
\hline Klebsiella & 2 & 2 & \\
\hline Haemophilus & 2 & 2 & \\
\hline Diphtheroids & 4 & 2 & 1 \\
\hline Neisseria & 5 & 5 & 2 \\
\hline Candida albicans & 5 & 5 & 5 \\
\hline Bacteroides & 5 & 5 & 5 \\
\hline Proteus & & & 4 \\
\hline $\begin{array}{l}\text { Propionibacterium } \\
\text { Anaerobic streptococci }\end{array}$ & & & \\
\hline Pneumococci. & 1 & 1 & \\
\hline Micrococci & & & \\
\hline
\end{tabular}


Table 5 Median and range of total organism count in the duodenums of infants in groups 1,2, and 3

\begin{tabular}{llll}
\hline & Group 1 & Group 2 & Group 3 \\
\hline Median & $2.3 \times 10^{5}$ & $1.8 \times 10^{5}$ & $1.4 \times 10^{7}$ \\
Range & $3.0 \times 10^{1-2.3} \times 10^{7}$ & $2.6 \times 10^{4}-9.5 \times 10^{5}$ & $5.7 \times 10^{6-3.3} \times 10^{7}$ \\
\hline
\end{tabular}

organisms isolated from the duodenum and the bacterial count per $\mathrm{ml}$ of duodenal juice for individual organism isolates in each group are in Fig. 1-3.

In all patients the organisms isolated from the duodenal juice were also isolated from the throat swab or the gastric aspirate. In many instances the same organism was isolated from all 3 sites. In contrast the flora isolated from the stool culture showed some qualitative differences from those of the duodenum. Eighteen different organisms were isolated from the duodenums of infants in group 1 and 2, and 21 from those in group 3. Of the individual duodenal organisms cultured $57 \%(29 / 51)$ in group 1 and $58 \%(28 / 48)$ in group 2 were present in a count of less than $10^{4}$ organisms $/ \mathrm{ml}$, whereas only $30 \%(20 / 66)$ were below this value in group 3 . The median total duodenal organism count in group 3 was almost 100 times greater than that of either of the other 2 groups (Table 5).

In comparing the individual organisms of the 3 groups, Escherichia coli occurred in greater

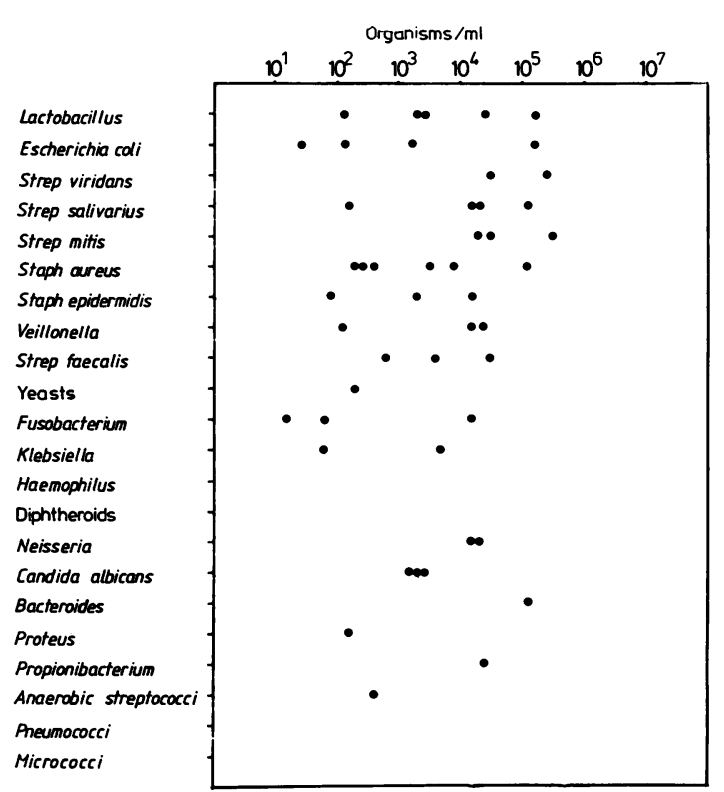

Fig. 2 Bacterial flora and organism count/ml of duodenal juice in group 2 infants.

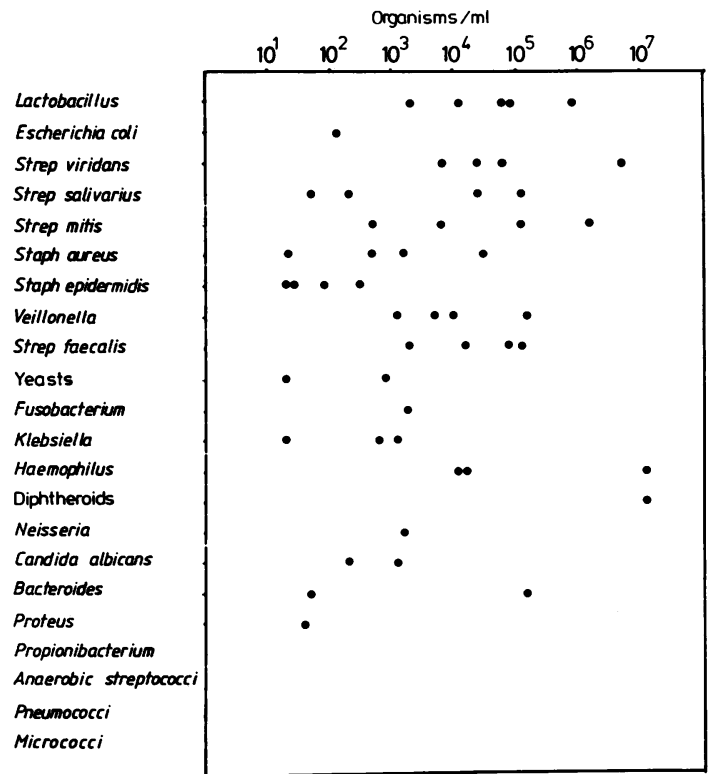

Fig. 1 Bacterial flora and organism count $/ \mathrm{ml}$ of duodenal juice in group 1 infants. 
numbers and with greater frequency in group 3. Comparing each group with the other 2 this difference was significant between groups 1 and 3 $(P<0.05)$ but not between groups 1 and 2 or group 2 and 3.

Other organisms were isolated where there were noticeable differences between groups but these differences failed to reach statistical significance. The organisms were Streptococcus viridans, Streptococcus mitis and Candida albicans $(\mathrm{P}=0.07)$; and Bacteroides $(\mathrm{P}=0.06)$. As with $E$. coli these organisms occurred with greater frequency and in greater numbers in group 3.

\section{Discussion}

On admission to hospital the 3 groups of infants were clinically indistinguishable. Their ages and weights were similar and all appeared to have had an acute onset of infectious diarrhoea. Their subsequent clinical course differed in that those in group 1 had rapid resolution of diarrhoea within 72 hours, whereas in groups 2 and 3 diarrhoea persisted beyond this period.

A luxuriant bacterial flora was present in the duodenums of all the infants. These organisms were also found either in the gastric aspirate or the throat swab, supporting previous suggestions that the upper small intestine is colonised from above.91011 The duodenal flora in infants with acute self limiting diarrhoea (group 1) was qualitatively and quantitatively similar to that of infants whose diarrhoea persisted after 4 days in hospital (group 2). The number of different organisms isolated was the same for each group and the majority of organisms were present in counts of less than $10^{4}$ organisms $/ \mathrm{ml}$. These findings differed from those of the group in which diarrhoea still persisted after 7 days in hospital (group 3). The number of different individual organisms isolated was only slightly higher but the majority of organisms were present in counts exceeding $10^{4}$ organisms $/ \mathrm{ml}$. The median total organism count was almost 100 times greater than that of the other 2 groups.

$E$. coli was isolated more often and in greater numbers in groups 2 and 3 than in group 1. The difference between groups 1 and 3 was statistically significant while that between groups 1 and 2 was not. Typing for enteropathogenicity and toxin production was not undertaken in this study so the relevance of this finding is not known. The results suggest that the presence of $E$. coli in the duodenum might constitute an important difference between infants with acute self limiting diarrhoea and those in whom diarrhoea persists. This warrants further investigation. Although Bacteroides, Streptococci and $C$. albicans occurred more often and in greater numbers in the group 3 infants this difference did not reach statistical significance.

The duodenal flora in all 3 groups differed markedly from that found in healthy infants. ${ }^{9}$ What constitutes the normal duodenal flora is controversial. The duodenum may be sterile, ${ }^{912} 13$ but a transient flora with a total bacterial count rarely exceeding $10^{4}$ organisms $/ \mathrm{ml}$ is regarded as normal by many. ${ }^{3} 511$ With the exception of 1 infant in group 1 the total bacterial count of all the infants studied exceeded this and may be regarded as abnormal.

Previous studies have suggested that infants with acute diarrhoea have increased numbers of organisms in the upper small bowel. ${ }^{614}$ The studies are limited in number and do not indicate whether the episode of diarrhoea was short lived or not. For this reason a valid comparison between these infants and those in group 1 is not possible. The group 3 infants had an upper small bowel flora similar to that of infants with protracted diarrhoea as described by Challacombe et al. ${ }^{1}$ The total duodenal organism count in the group 3 infants and those studied by Challacombe was quantitatively much greater than that of infants who had diarrhoea for less than 6 days (groups 1 and 2). While the infants in group 3 were studied 7 to 9 days after the onset of the acute illness those in Challacombe's study had diarrhoea for a minimum of 14 days prior to investigation. It appears that the duodenal bacterial overgrowth found in infants with protracted diarrhoea is established 6 to 9 days after the onset of the acute illness.

The results of this study may have important implications for treatment. If it is accepted that the overgrowth of organisms in the duodenum of infants with protracted diarrhoea is in some way responsible for prolonging the disease specific treatment ${ }^{4}$ should be given about 7 days after the onset of the acute illness. Failure to do so may result in a vicious cycle, where persistence of the diarrhoea leads to malnutrition which further aggravates the diarrhoea.

\section{References}

1 Challacombe D N, Richardson J M, Rowe B, Anderson C M. Bacterial microflora of the upper gastrointestinal tract in infants with protracted diarrhoea. Arch Dis Child 1974; 49: 270-7.

2 Lifshitz F. The enteric flora in childhood diseasediarrhea. Am J Clin Nutr 1977; 50: 1811-8.

3 Gorbach S L. Intestinal microflora. Gastroenterology 1971; 60: 1110-29.

4 Hill I D, Mann M D, Bowie M D. Successful management of persistent diarrhoea in infants. $S$ Afr Med J 1980; 58: 241-3. 
5 Coello-Ramirez P, Lifshitz F. Enteric microflora and carbohydrate intolerance in infants with diarrhea. Pediatrics 1972; 49: 233-42.

6 Heyworth B, Brown J. Jejunal microflora in malnourished Gambian children. Arch Dis Child 1975; 50: 27-33.

7 Hill I D, Mann M D, Bowie M D. Hypernatraemic dehydration. A prospective study in children with diarrhoeal disease. $S$ Afr Med J 1981; 59: 479-81.

8 Draser B S. Cultivation of anaerobic intestinal bacteria. J Pathol Bacteriol 1967; 94: 417.

- Challacombe D N, Richardson J M, Anderson C M. Bacterial microflora of the upper gastrointestinal tract in infants without diarrhoea. Arch Dis Child 1974; 49: 264-9.

10 Draser B S, Shiner M, McLeod G M. Studies on the intestinal flora. I. The bacterial flora of the gastrointestinal tract in healthy and achlorhydric persons. Gastroenterology 1969; 56: 71-9.

11 Lloyd-Still J, Schwachman H. Duodenal microflora. A prospective study in paediatric gastrointestinal disorders. Dig Dis 1975; 20: 708-15.

12 Cohen R, Kalser M H, Arteaga I, et al. Microbial intestinal flora in acute diarrheal disease. JAMA 1967; 201 : 835-40.

13 Donaldson R M, Jr. Normal bacterial populations of the intestine and their relation to intestinal function. $N$ Engl $J$ Med 1964; 270: 938-45.

14 Neto U F, Toccalino H, Dujovney F. Stool bacterial aerobic overgrowth in the small intestine of children with acute diarrhoea. Acta Paediatr Scand 1976; 65: 609-15.

Correspondence to Dr I D Hill, Department of Paediatrics and Child Health, Red Cross War Memorial Children's Hospital, Rondebosch 7700, Republic of South Africa.

Received 29 December 1982

\section{Technical editor}

Jennifer Orton who has been technical editor of the Archives since 1978 has moved away from London and has had to give up her post. She has been a most loyal and able technical editor who has taken immense trouble with every manuscript. Many authors and particularly those from overseas will have been grateful to her for her skilful editing. Authors and readers will join the editors in thanking her and wishing her a happy future. Norma Cosgrave has been appointed as the new technical editor.

\section{Editorial committee}

Dr N D Barnes recently completed his 5 year term as a member of the Editorial committee. We are grateful to him for his careful work and loyal assistance. Professor E D Alberman, clinical epidemiologist, London Hospital Medical College; Dr J M H Buckler, paediatric endocrinologist, Leeds; and Dr R O Robinson, paediatric neurologist, Guy's Hospital, London, have joined the Editorial committee. 